\title{
The Pain Relief and Recalcification Results of Radiotherapy for Plasma Cell Tumors
}

\author{
Fatma SERT $^{1}$, Serra KAMER ${ }^{1}$, Guray SAYDAM ${ }^{2}$, Yavuz ANACAK ${ }^{1}$ \\ ${ }^{1}$ Ege University, Faculty of Medicine Department of Radiation Oncology \\ ${ }^{2}$ Ege University, Faculty of Medicine Department of Hematology, Izmir, TURKEY
}

\begin{abstract}
Multiple Myeloma (MM) and Solitary Plasmocytoma (SP) are given as Plasma Cell Neoplasms (PCNs). Radiotherapy (RT) is used for definitive and/or palliative purposes. We aimed to evaluate the role of $\mathrm{RT}$ upon pain relief,recalcification and local disease control for the patients with PCNs. From January 2009 to December 2016, total 80 patients were evaluated. Eleven (13.8\%) patients were classified as SP, and $69(86.3 \%)$ were as MM. The total treatment dose was 45 Gy with 1.8 Gy per fraction for the SP and total 30 Gy with 2.53 Gy per fraction for the MM. Numerical Rating Pain Scale (NRS) was used for pain level detection and the international consensus on palliative RT criteria was used for recalcification level classification before and after RT. Prior to RT, 56 (70\%) patients suffered from severe pain, 19 (23.8\%) patients suffered from moderate pain and only 5 (6.3\%) patients reported mild pain. After RT, complete pain relief was achieved in 59 (73.8\%) and partial pain relief was reported remaining 14 (17.5\%) patients. We identified some kind of radiologic recalcification response in 77 (96.3\%) patients. Complete and partial radiological response was recorded in 41 (51.3\%) and $36(45 \%)$ patients, respectively. Complete recalcification response was seen in 9 of 11 (82\%) SP patients and 32 of 69 (46\%) MM patients. The difference of complete recalcification response rates between two groups was significant $(p=0.031)$.Local disease control was achieved in 75 (94\%) patients. The time interval after RT and applied RT doses are important factors for recalcification effect. Unlikely, pain relief can be achieved regardless of dose level. It can be stated that treatment doses over 30 Gy with multiple fractions should be suggested for the patients in good general condition with a life expectancy of $>1$ year.
\end{abstract}

Keywords: Multiple myeloma, Plasmocytoma, Pain relief, Recalcification, Radiotherapy

ÖZET

\section{Plasma Hücreli Tümörlerde Radyoterapinin Ağrı Kesici ve Rekalsifikasyon Etkisi}

Multipl myelom (MM) ve Soliter Plazmositom (SP), Plasma Hücreli Tümörlerdir (PHT). Radyoerapi (RT) PHT'lerde definitif ve/veya palyatif amaçla tedavinin bir parçası olarak kullanıı. PHT'lerde RT'nin ağrı kesici, rekalsifikasyon ve lokal hastalık konrol etkisini araştırmayı amaçladık. Ocak 2009-Aralık 2016 tarihleri arasında, 11 (14\%) SP ve 69 (\%86) MM tanılı toplam 80 hastayı değerlendirdik. Toplam tedavi dozu, SP için 1.8 Gy fraksiyon dozu ile 45 Gy, MM için 2.5 Gy fraksiyon dozu ile 30 Gy’dir. Tedavi öncesi ve sonrası olmak üzere, ağri seviyesi için Numerical Rating Pain Scale (NRS) ve rekalsifikasyon için uluslararası konsensus kriterleri kullanılmıştır. RT öncesi, ciddi, orta ve ıımlı ağı mevcut olan hasta sayısı sırasıyla 56(\%70), 19 (\%24) ve 5 (\%6)'dır. RT sonrası, tam ve kısmi ağrı azalması yanıtı sırasıyla 59 (\%74) ve 14 (\%18) hastada elde edilmiştir. Herhangi bir radyolojik yanıt 77 (\%96) hastada elde edilmiştir. Tam ve kısmi radyolojik yanıt oranları sırasıyla 41 (\%51) ve 36 (\%45) hastada izlenmiștir. Tam rekalsifikasyon yanıtı 11 SP'un 9 (\%82)'unda, 69 MM'un 32 (\%46)'sinde elde edilmiştir. Bu farklılık istatistiksel olarak anlamlıdır ( $p=0.031$ ). Lokal hastalık kontrolü 75 (\%94) hastada elde edilmiştir. RT sonrası geçen zaman ve uygulanan RT dozu, rekalsifikasyon için önemli faktörlerdir. Farklı olarak, ağrı kesici etkisi uygulanan RT dozundan bağımsızdı. Yaşam beklentisi > 1yıl olan genel durumu iyi hastalara çoklu fraksiyonlarla 30 Gy'in üzerinde tedavi dozları önerilebilir.

Anahtar Kelimeler: Multipl myelom, Plazmositom, Ağrı kesici, Rekalsifikasyon; Radyoterapi

ORCIDs: Fatma SERT: 0000-0001-6052-8614 Guray SAYDAM: 0000-0001-8646-1673
Serra KAMER: $\quad$ 0000-0001-8316-9976

Yavuz ANACAK: 0000-0002-4085-5025 


\section{INTRODUCTION}

Plasma Cell Neoplasms (PCNs) are a group of diseases characterized by abnormal increase of plasma cells in bone marrow and other tissues. Multiple Myeloma (MM) is the most common type of PCNs where systemic disease with bone marrow involvement is present. ${ }^{1}$ On the other hand, Solitary Plasmocytoma (SP) is considered as a local disease with a potential to progress towards MM. Usually a lytic bone lesion or occasionally a soft tissue mass of plasma cells without bone marrow involvement characterizes SP. MM is 16 times frequent than SP. ${ }^{1}$

Proliferation of the plasma cells inside the bone marrow initially causes the destruction of the medullary bone structures, followed by involvement of the cortical bone which may result in a lytic destructive mass penetrating to neighboring structures. Recurrent bone pain, soft tissue masses, anemia, infections, neurological symptoms, hypocalcemia and renal failure are typical clinical features of PCNs. ${ }^{2}$ Osteolysis due to increased osteoclast activity causes pathologic fractures and serious bone pain which seriously impact on quality of life of the patients. ${ }^{3}$

Radiotherapy (RT) alone is a definitive treatment choice for SP where moderate doses of radiation are good enough for cure 3. RT has also an important role in the management of MM by reducing painful osteolytic process and improving recalcification. ${ }^{2}$ RT prevents pathologic fractures, controls serious bone pain and reduces analgesic usage. Moreover, ensuring bone remodulation of lytic bone lesions caused by malign tumor infiltration is accepted as a secondary and long term effect of RT for this group of patients. ${ }^{1}$

The optimal dose fractionation of RT for MM is not known yet. Radiation doses ranging from single fraction of 8 Gy to 20 fractions of 2 Gy in 4 weeks were used to treat painful bone lesions of MM for palliative purposes. However, current literature is not clear yet for giving an exact message regarding the role of RT, adequate dose-fractionation and the relation between radiation dose and recalcification. ${ }^{4,5}$

In this paper, we evaluated the role of RT in the treatment of PCNs to determine the impact of ra-

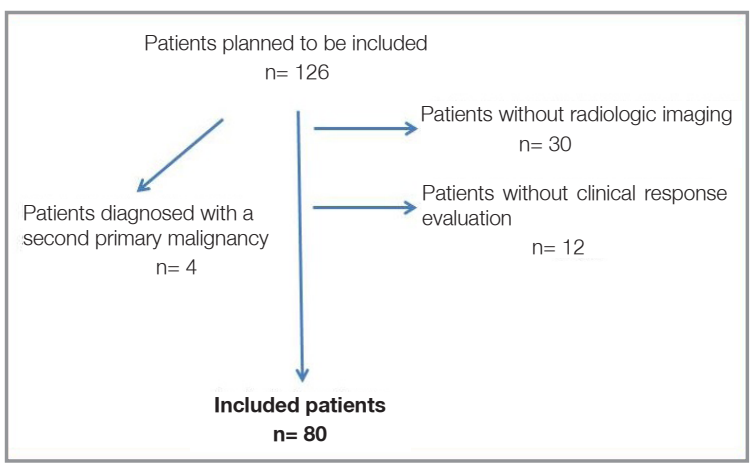

Figure 1. Evaluation flow chart of included patients

diation on pain relief, recalcification and local disease control. Our study is unique in terms of being a single research designed prospectively to evaluate the relation between recalcification and radiation dose level for PCNs.

\section{PATIENTS AND METHODS}

From January 2009 to December 2016, we recorded one hundred and twenty six patients with the diagnosis of PCNs (either SP or MM) treated with RT at Ege University. Thirty patients without radiologic and/or clinical response evaluation were excluded due to the difficulty of comparison. In addition, 4 patients diagnosed with a seconder malignancy and all the patients with the diagnosis of extramedullary SPs were excluded from our trial population. Finally, 80 patients were included in this study cohort. Patient evaluation flow chart is presented in Figure 1. Both radiological and clinical evaluations were performed prospectively. For radiologic response evaluation, either plain X-ray or CT was used. The Research Ethics Board approval was obtained from Ege University Ethic Committee with the decision number 15-5.1/9.

The characteristics of patients were presented in Table 1. Out of 80 patients, 11 (13.8\%) were classified as SP, and $69(86.3 \%)$ were classified as MM according to the International Myeloma Working Group's Criteria 6. Patients with SP received RT alone and patients with MM received chemotherapy and RT. Surgery due to spinal compression or bone fracture was performed in 20 patients (25\%) immediately followed by RT, and prophylactic sur- 
Table 1. The characteristics of the included patients

\section{Characteristics}

Patients No (\%)

Gender

Female

$35(43.8 \%)$

Male

$45(56.3 \%)$

Age at Diagnosis

Median (years)

58

Range (years)

36-88

Stage at Diagnosis

Solitary Plasmacytoma $\quad 11(13.8 \%)$

Multiple Myeloma

$69(86.3 \%)$

Treatment

Definitive Radiotherapy

$10(12.5 \%)$

Radiotherapy prior to Chemotherapy

$18(22.0 \%)$

Radiotherapy after Chemotherapy

$52(65.0 \%)$

Surgery

Yes

$15(18.8 \%)$

No

$65(81.3 \%)$

Treated Sites

Vertebral Bones

$44(55.0 \%)$

Pelvic Bones

7 (8.8\%)

Skull

$5(6.3 \%)$

Extremities

$11(13.8 \%)$

Ribs

$4(5.0 \%)$

Scapula

$2(2.5 \%)$

Clavicle

$7(8.8 \%)$

Pain Intensity before Radiotherapy

Mild

$5(6.3 \%)$

Moderate

$19(23.8 \%)$

Severe

gery prior to RT was performed in 20 patients who have high risk of fracture in weight bearing bones.

Megavoltage linear accelerators were used for irradiation and appropriate photon energy levels were selected according to involved bone site. Gross tumor volume (GTV) covered the osteolytic lesion and its extension to soft tissue and bone marrow, Clinical Target Volume (CTV) was determined according to the potential involved microscopic disease sites and a margin of 1 to $1.5 \mathrm{~cm}$ as a Planning Target Volume (PTV) was determined according to involved bone 7 . The total treatment dose was 45 Gy with 1.8 Gy per fraction for the patients with

SP and 30 Gy with 2.5-3 Gy per fraction for the patients with MM. At least $95 \%$ of the PTV received the $95 \%$ of the prescription dose in all treatment plans.

Numerical Rating Pain Scale (NRS) was used for pain level evaluation 8 . A pain score $\leq 4$ was classified as mild, 5-7 as moderate and severe if the pain score was $\geq 88$. All patients were evaluated in terms of their pain intensity before RT (called as basal pain score) by using NRS and they were reevaluated 45 days after their RT treatment by using NRS, as well. The pain response rate was defined according to the international consensus on palliative RT criteria9.

The presence of osteolyitic lesions were confirmed by X-ray or computed tomography (CT) prior to RT (basal radiologic evaluation). X-ray/CT was repeated at least 6 months later to evaluate the recalcification effect of RT. All radiologic assessment was performed by a radiologist specialized in musculoskeletal system. International consensus on palliative radiotherapy was used for the recalcification evaluation10. Monthly bisphosphonate (zoledronic acid IV $4 \mathrm{mg}$ ) treatment was prescribed for a minimum duration of 6 months to all patients. Bisphosphonate related mandible osteonecrosis was closely monitored by local examination and mandible orthopantomograhic X-ray. ${ }^{10-12}$

The median follow-up was 25 (range, 6-84 months) months. Local disease control was defined as the absence of both new osteolytic lesions and pain at the initial irradiated site based on the basal evaluations.

We had a limitation in this research. We could not analyze the relation between the biochemical parameters and the recalcification response of the patients due to the lack of required data. We could compare the results of hemoglobin status with the recalcification status.

SPSS (Statistical Package for the Social Sciences, Chicago, IL, USA) version 21.0 was used for statistical analysis. Frequency analyses were performed for obtaining descriptive data. Chi-squared test was used to analyze the differences among groups in terms of pain relief, radiologic response and toxicity. Univariate analysis was performed by the 


\begin{tabular}{|ll|}
\hline $\begin{array}{l}\text { Table 2. The rate of patients' recalcification response ac- } \\
\text { cording to the evaluation criteria }\end{array}$ \\
\hline Recalcification Level & $\mathbf{n}(\%)$ \\
\hline Complete Response & $41(51.3 \%)$ \\
Partial Response & $36(45.0 \%)$ \\
Stable Response & $3(3.8 \%)$ \\
Progressive Response & 0 \\
\hline
\end{tabular}

Kaplan-Meier method to analyze factors affecting disease control, with comparison using a log-rank test. A $p$ value of $<0.05$ was considered statistically significant.

\section{RESULTS}

\section{Recalcification}

We identified some kind of radiologic recalcification response in $77(96.3 \%)$ patients at 6 months after the treatment. Complete and partial radiological responses were recorded in $41(51.3 \%)$ and 36 $(45 \%)$ patients, respectively. Only $3(3.8 \%)$ patients had stable radiological response after RT (Table 2). Complete recalcification response was seen in $82 \%$ of SP patients and $46 \%$ of MM patients. The difference of complete recalcification response rates between two diagnostic groups was statistically significant $(p=0.031)$. Recalcification response was detected significantly more in the patients treated with total 45 Gy than the patients treated with total $30 \mathrm{~Gy}(\mathrm{p}<0.001)$. We did additional statistical analysis according to diagnosis in order to see the difference between the diagnostic groups. Complete and partial recalcification response rate was statistically higher for the patients with $\mathrm{SP}(\mathrm{p}=$ 0.031 and $\mathrm{p}=0.002$, respectively). Hemoglobin levels were compared by using the cut-off level of $8.0 \mathrm{~g} / \mathrm{dL}$ and we found positive impact of having $\geq 8 \mathrm{~g} / \mathrm{dL}$ of hemoglobin level over recalcification response $(\mathrm{p}=0.032)$.

\section{Pain Relief}

Prior to RT, 56 (70\%) patients were suffered from severe pain, $19(23.8 \%)$ patients were suffered from moderate pain and only $5(6.3 \%)$ patient had mild pain. Forty-nine of $69(71 \%)$ MM patients

\begin{tabular}{|ll|}
\hline $\begin{array}{l}\text { Table 3. The rate of patients' pain relief according to the de- } \\
\text { scribed international consensus on palliative RT criteria }\end{array}$ \\
\hline Pain Relief & $\mathbf{n}(\%)$ \\
\hline Complete Response & $59(73.8 \%)$ \\
Partial Response & $14(17.5 \%)$ \\
Stable Pain & $7(8.8 \%)$ \\
Pain Progression & 0 \\
\hline
\end{tabular}

and 7 of $11(63 \%)$ SP patients had severe pain. Median NRS was 2 (range, 1-4), 5 (range, 5-7) and 9 (range, 8-10), respectively for the patients with mild, moderate and severe pain.

After 45 days from RT, no patients reported an increased in their pain level. On the other hand, 7 (8.8\%) patients had no change in their pain level. Complete pain relief was achieved in $59(73.8 \%)$ and partial pain relief was reported remaining 14 (17.5\%) patients. Additionally, 20 of those 59 patients complete pain response were analgesic-free. Median NRS 45 days after RT was 2 (range, 0-6) for all treated patients. We could not find any statistically significant difference in terms of pain relief between two diagnostic groups. The distribution of pain relief according to baseline pain level is shown in Table 3.

\section{Local Disease Control}

Local disease control was achieved in 75 (94\%) patients. Local disease progression was seen in 5 (6\%) MM patients and time to local disease progression times were 5, 7, 9, 11 and 12 months, respectively. In median 25 months, 2-years local disease control rates were $93.5 \%, 92.4 \%$ and $100 \%$ for all patients, patients with MM and patients with $\mathrm{SP}$, respectively $(\mathrm{p}=0.352)$. 2-years overall survival rates were $83.5 \%, 80.8 \%$ and $100 \%$ for all patients, patients with $\mathrm{MM}$ and patients with SP, respectively $(p=0.117)$. We could not show any effect of applied radiation dose to local disease control $(\mathrm{p}=0.352)$.

\section{Adverse Effects}

In the acute and chronic adverse effect evaluation done by using Radiation Therapy Oncology Group 
(RTOG) scale, none of patients had grade 3-4 adverse effects due to the radiotherapy.

\section{DISCUSSION}

\section{Pain Relief}

It is known that analgesic effect of RT can be obtained during or immediately after RT in PCNs. This can be partial pain relief in $80-90 \%$ of patients and complete pain relief in $50 \%$ of patients. ${ }^{12,13} \mathrm{On}$ the other hand, the effect of radiation dose on pain relief has not been clear yet. All present data comes from the treatment of solid tumor bone metastases. But the results of those randomized trials do not show superiority of any particular RT regimen. ${ }^{14}$ The role of different RT dose levels for PCNs is not established clearly.

Van der Linden YM et al evaluated the Dutch Bone Metastasis Study results which was comparing the single 8 Gy fraction efficacy with the multiple fractions..$^{15}$ They reanalyzed and recalculated the database on all randomized patients responses to initial treatment and retreatment. They found that single fraction and multiple fractions RT provided equal palliation for painful bone metastases. Overall, they concluded that retreatment was effective in $63 \%$ of retreated patients. ${ }^{15}$ On the other hand, Adamietz IA et al. ${ }^{16}$ and Minowa $\mathrm{Y}$ et al. ${ }^{17}$ stated that the higher doses needed for adequate pain relief in MM patients. Adamietz IA et al. evaluated the palliative RT effect in the records of $70 \mathrm{MM}$ patients. ${ }^{16}$ They found that higher doses could provide long-term local palliation. A German randomized trial comparing 1x8 Gy vs 10x3 Gy treatment schedules showed that high doses had better biological efficacy and stabilization. ${ }^{18}$ More recently, Rudzianskiene $\mathrm{M}$ et al. ${ }^{19}$ compared the single 8 Gy dose with multiple fractions (10x3 Gy) and observed same analgesic effect for both dose levels. Radiotherapy is the accepted standard treatment approach for SP. Nevertheless there is limited data for SP in current literature due to its rarity. A retrospective data from Germany, University of Rostock, evaluated the pain reduction and recalcification effect of RT for the patients with SP. ${ }^{3}$ They included 138 patients with 272 irradiated targets. They reported that pain relief obtained in $85 \%$ of SP patients with RT. Treatment doses up to 40-50 Gy with multiple fractions was suggested for the patients in good general condition with a life expectancy of $>1$ year in their conclusion. ${ }^{3}$ Krause $\mathrm{S}$ et al evaluated the role of RT in 18 patients diagnosed with SP. They found that RT still had an important role for local disease control of SP. However, they did not evaluate the dose-effect relationship with pain relief. ${ }^{20}$

Our data showed that $73(91.3 \%)$ patients had pain relief (complete/partial response) with RT. Only 7 (7.8\%) patients had stable pain response with RT. When the patients evaluated in terms of their diagnosis, it was seen that 10 of 11(91\%) SP and 49 of $69(71 \%)$ MM patients had complete pain response with RT. Analgesic reduction without any pain increase was observed in $14(20 \%)$ patients with MM. The remaining patients, who had moderate and severe pain level at the evaluation before RT, presented pain score of mild $(\leq 4)$ after RT but it was obtained with the help of analgesic support.

\section{Recalcification}

Balducci $\mathrm{M}$ et al found that a radiological response was achieved in $50 \%$ of patients with median 38 Gy total doses after RT and complete radiological response was identified in $38 \%$ of included patients, remains were identified as partial. ${ }^{2}$ Stölting $\mathrm{T}$ et al found that higher doses could achieve higher rate of recalcification and concluded that if the total dose level were $\geq 50 \mathrm{~Gy}$, the rate of recalcification would be $68.8 \%$. This difference was found statistically significant $(p=0.041) 3$. In the trial of Matuschek $\mathrm{C}$ et al, the recalcification rate was $48 \%$ in all irradiated bone lesions. Median radiation dose was 25 Gy with 2.5 Gy per fraction (range, 8 Gy to $50 \mathrm{~Gy}$ ). In their uni- and multivariate analysis, higher radiation doses were significantly associated with a higher likelihood of recalcification $(p=0.0048) .{ }^{19}$ In the prospective randomized study of Rudzianskiene $\mathrm{M}$ et al, single vs multiple fractionation regimens were compared in terms of recalcification effect. ${ }^{14}$ Recalcification response was obtained in 32/101 patients $(33.7 \%)$ : complete in $17(53.2 \%)$ and partial in $15(46.2 \%)$. They reported that no significant differences were observed in recalcification rates between two dose levels for MM patients. On the other hand, they 
emphasized that recalcification rates were affected significantly by performance status, haemoglobin level and stage of disease. ${ }^{14}$

Our recalcification response rate was $96.3 \%$ for all patients. However, complete response was identified only $51.3 \%$ of patients. We found statistically significant difference between $30 \mathrm{~Gy}$ and $45 \mathrm{~Gy}$ dose levels $(p=0.031)$.

\section{Conclusion}

Radiotherapy has a central role in the management of PCNs. The time interval after RT and applied RT doses are important factors for obtaining a demonstrable recalcification effect of radiation. Unlikely, pain relief can be achieved regardless of dose level. It can be stated that treatment doses over $30 \mathrm{~Gy}$ with multiple fractions should be suggested for the patients in good general condition. Response of SP might be better to RT than MM. Bisphosphonate (zoledronic acid iv $4 \mathrm{mg}$ ) treatment used concomitantly can support recalcification effect of RT.

\section{REFERENCES}

1. Dores GM, Landgren O, McGlynn KA, et al. Plasmacytoma of bone, extramedullary plasmacytoma, and multiple myeloma: incidence and survival in the United States, 1992-2004. Br J Haematol 144: 86-94, 2009.

2. Balducci M, Chiesa S, Manfrida S, et al. Impact of radiotherapy on pain relief and recalcification in plasma cell neoplasms: long-term experience. Strahlenther Onkol 187: 114-119, 2011.

3. Stölting $\mathrm{T}$, Knauerhase $\mathrm{H}$, Klautke $\mathrm{G}$, et al. Total and single doses influence the effectiveness of radiotherapy in palliative treatment of plasmacytoma. Strahlenther Onkol 184: 465$472,2008$.

4. Dimopoulos MA, Goldstein J, Fuller L, et al. Curability of solitary bone plasmacytoma. J Clin Oncol 10: 587-590, 1992.

5. Farhangi M, Ossermann E. The treatment of multiple myeloma. Semin Hematol 10: 149-161, 1973.

6. International Myeloma Working Group. Criteria for the classification of monoclonal gammopathies, multiple myeloma and related disorders: a report of the International Myeloma Working Group. Br J Haematol 121: 749-757, 2003.

7. Wambersie A, Menzel HG, Andreo P, et al. Isoeffective dose: a concept for biological weighting of absorbed dose in proton and heavier-ion therapies. Radiat Prot Dosimetry 143: 481486, 2011.
8. Cleeland CS, Ryan KM. Pain assessment: global use of the Brief Pain Inventory. Ann Acad Med Singapore 23: 129-138, 1994.

9. Chow E, Doyle M, Li K, et al. Mild, moderate, or severe pain categorized by patients with cancer with bone metastases. $J$ Palliat Med 9: 850-854, 2006.

10. Chow E, Wu JS, Hoskin P, et al. International consensus on palliative radiotherapy endpoints for future clinical trials in bone metastases. Radiother Oncol 64: 275-280, 2002.

11. Vassiliou V, Tselis N, Kardamakis D. Osteonecrosis of the jaws: clinicopathologic and radiologic characteristics, preventive and therapeutic strategies. Strahlenther Onkol 186: 367-373, 2010

12. Vakaet $L A$, Boterberg $T$. Pain control by ionizing radiation of bone metastasis. Int J Dev Biol 48: 599-606, 2004.

13. Halperin EC, Wazer DE, Perez CA, Brandy LW. Principles and Practice of Radiation Oncology. 6th edition. Philadelphia, Lippincott Williams and Wilkins, 2013: 130-203.

14. Rudzianskiene M, Inciura A, Gerbutavicius R, et al. Single vs. multiple fraction regimens for palliative radiotherapy treatment of multiple myeloma : A prospective randomised study. Strahlenther Onkol 193: 742-749, 2017.

15. van der Linden YM, Lok JJ, Steenland E, et al; Dutch Bone Metastasis Study Group. Single fraction radiotherapy is efficacious: a further analysis of the Dutch Bone Metastasis Study controlling for the influence of retreatment. Int J Radiat Oncol Biol Phys 59: 528-537, 2004.

16. Adamietz IA, Schöber C, Schulte RW, et al. Palliative radiotherapy in plasma cell myeloma. Radiother Oncol 20: 111 116,1991

17. Minowa $\mathrm{Y}$, Sasai $\mathrm{K}$, Ishigaki $\mathrm{T}$, et al. Palliative radiation therapy for multiple myeloma. Nihon Igaku Hoshasen Gakkai Zasshi 56: 1056-1060, 1996.

18. Koswig S, Budach V. Remineralization and pain relief in bone metastases after after different radiotherapy fractions (10 times 3 Gy vs. 1 time 8 Gy). A prospective study. Strahlenther Onkol 175: 500-5008, 1999.

19. Matuschek C, Ochtrop TA, Bölke E, et al. Effects of Radiotherapy in the treatment of multiple myeloma: a retrospective analysis of a Single Institution. Radiat Oncol 28: 71-80, 2015.

20. Krause S, Hillengass J, Goldschmidt H, et al Radiotherapy of solitary plasmacytoma. Ann Hematol 90: 1093-1097, 2011.

\section{Correspondence:}

Dr. Fatma SERT

Ege Üniversitesi Tip Fakültesi

Radyasyon Onkolojisi Anabilim Dali

Bornova, IZMIR / TURKEY

Tel: (+90-505) 7947536

e-mail: gracilis81@yahoo.com 